\title{
Effect of leadership, compensation, organizational culture and emotional intelligence on job satisfaction and employees performance
}

\author{
Ilham Andi Rahman ${ }^{1)}$, Mansyur Ramly ${ }^{2)}$, Muh. Nasir Hamzah ${ }^{3)}$, Roslina Alam ${ }^{4)}$ \\ ${ }^{1}$ (Doctoral Student in the Faculty of Economics, Muslim University of Indonesia) \\ ${ }^{2,3,4}$ (Faculty of Economics, Muslim University of Indonesia)
}

\begin{abstract}
This study is a survey study and implemented in 335 employees working the parent implementation units and all units implementing the state-owned electricity company PT. Perusahaan Listrik Negara (Persero) Region of South and West Sulawesi. Result Analysis of a Moment Structures (AMOS) provides evidence that leadership, compensation, organizational culture, and emotional intelligence and significant positive effect on job satisfaction. Other test results show that leadership, compensation, organizational culture, and emotional intelligence and significant positive effect on employee performance. Testing indirect effects provide evidence that leadership, compensation, organizational culture, and emotional intelligence positive and significant effect on the performance of employees through job satisfaction as variable. An intervening recently disclosed results that job satisfaction has a direct positive influence and significant impact on employee performance. The coefficient effects (direct effect) leadership, compensation, organizational culture, and emotional intelligence on employee performance are positive. Coefficient of indirect effects (indirect effects) exogenous variables on the performance of employees through job satisfaction is positive effect. The total effect is the sum of the direct and indirect effect through job satisfaction obtained a positive value, which means that there is the effect of the direct effects and the indirect effects of exogenous variables on performance through employee satisfaction
\end{abstract}

Keywords: Leadership, compensation, cultural, emotional, satisfaction, employee performance

\section{Introduction}

In Indonesia, the state-owned electricity company or PT. Perusahaan Listrik Negara (Persero), also known under the name. PT. PLN (Persero) is the holder of the monopoly license sales of electric energy, on the one hand should appear to be a good public service, while on the other hand the company is expected to be profit-oriented. Although PT. PLN (Persero) has brought about a large market share, but in practice, the expected profit margin was relatively small. As a result, the company only acts as a public service with quality products and services that are not reliable. Implementation of the vision and mission, the vision and mission of the regional declared as a company that is efficient, satisfying, and supported by Human Resources professionals.

Various efforts have been done by the company in enhancing professionalism and improving employee performance, but the company still encountered significant disincentive, particularly in meeting the demands of the life of a number of increasingly complex society, including the demands of a small number of people to avoid the increase in electricity tariff, and society can be served as subscribes to those who have access to electricity. In other parts of the company have the ability to power (electrical energy) is very limited. This shows the imbalance between the numbers of applicants with the ability of electric energy available.

The results of observations discovered a phenomenon associated with the human resources of the company, it appears there are employees who do not take advantage of the time it works well as coming late to work, not in place when it should be still on duty, leaving work earlier than the rest time is specified, many employees are resting or relaxed during working hours and leave office before curfew. In connection with various problems, certainly impact on the performance of individuals and organizations. The challenges arise from the public is how the company continues to maintain its original quality with sufficient power supply to the community, especially with the increase in electricity tariffs. This is directly related to the use of the budget to assist in planning, coordinating and controlling the applied system. Budget preparation would have to be evaluated and the strict control that the company afloat on the basis of existing policies.

Leadership is an important element in the company; previous studies provide evidence that leadership is positive and significant impact on job satisfaction and employee performance (Sukarjati et al., 2016). Another study provides new evidence that the leadership is a negative and significant effect on employee performance 
(Muhammad Rasbi, 2016). Another condition that occurs in the company is the provision of compensation in the form of overtime pay is sometimes not in accordance with a predetermined time. For example, overtime should come at the end of the month when overtime but come at the beginning of a new month. This resulted in the employees will feel valued so that work does not optimum. In addition, other phenomena indicating the low compensation of employees' looks employees do not take advantage of the time it works well as late in the office, not in place of duty, leaving work earlier than the rest period is specified, many employees who break or relaxing during working hours and left the office before curfew. Empirical evidence suggests that the compensation can improve employee performance (Condly et al., 2003: 58). The findings of other researchers, proves that the compensation positive and significant impact on job satisfaction and employee performance (Siti Arofah, 2015; Supatmi, et al., 2013).

The rapid development of the company can be determined by the organizational culture of the company, because culture is a form of basic assumptions that discovered and developed the group through a learning process and involves the integration of external problems and internal problems of the organization (Schein, 1991). Organizational culture at PT. PLN (Persero) has not been able to form a company to be strong because of the values of the organization have not been socialized properly to each employee, in which there are employees who act as they pleased without regard to values, ethics, and the rules and regulations including chatting during working hours, no mutual respect, concern for fellow employees are still lacking, it is not capable of various and cooperate with other employees. In fact, the development organization aimed at creating a culture that encourages and appreciates the performance of fellow employees. Results of previous studies proving that organizational culture have a significant effect on job satisfaction and employee performance (Duwit, 2015; Khanifah \& Palupiningdyah, 2015; Melina Taurisa \& Intan, 2012). Other deciding factor in improving employee satisfaction and performance is emotional intelligence (Agustian, 2001:26). Past research provides evidence that emotional intelligence has an influence on job satisfaction and employee performance (Supriyanto \& Troena, 2012; Khanifah \& Palupiningdyah, 2015). Differences in study results provide new evidence that emotional intelligence not significant effect on job satisfaction and employee performance (Carmeli, 2003; Duwit, 2015).

\section{Leadership}

\section{Literature Review}

Scientists generally define leadership in accordance with the perspectives of the individual and the aspects of the phenomenon that most caught his attention like, Leadership is the relationship in the which one person, or the leader, influences others to work together willingly on related tasks to ATTAIN that roommates the leaders desire (Terry, 1977: 458). In the other part of leadership is described as the ability to influence a group toward the achievement of targets. Appreciate the leadership that use behavior, build teamwork, morale and help encourage subordinates to achieve the goal; it can improve the performance and job satisfaction (Robbins, 2007: 432). There are positive influence between leadership and job satisfaction of subordinates. Effective reasons must be able to provide guidance in labor effort to achieve organizational goals. Therefore, leaders must be able to influence the behavior of his subordinates in carrying out the tasks to achieve organizational objectives, either individually or in groups (Gibsons, 2003).

Smith (1996: 162) identifies five behaviors of effective leaders, namely: (1) the challenging behavior of risk; the leader who enjoyed the challenge (risk) that encourages subordinates to do the same, where the leader is likely to follow technological developments, changes and learning processes; (2) promote behavior change vision, the intuitive behavior of the leader, had a vision and thinking far ahead; (3) behavioral motivator, namely those who will motivate subordinates to do the best, empowering subordinates, establish teamwork, and work well together so that subordinates feel strong and supportive; (4) guiding behavior, the behavior of leaders who lead and teach values, tasks based on labor standards set; and (5) supportive behavior, the behavior of leaders supporting, encouraging subordinates and reward for his achievements. Based on these explanations can be concluded that in order to increase job satisfaction and employee performance in an organization really needed a leader who is able to move throughout the organization to work well. Some things to consider being able to lead well, such as: compensation, supervisory leadership, inspirational leadership, charismatic leadership, and intellectual stimulation

\section{Compensation}

The provision of compensation or remuneration was one factor that is very important both for the sake of jobs and for the benefit of the organization, Compensation for the organization is a financing element; on the other hand for employee compensation is a determinant of social status in society. According to Mondy \& Noe (2003: 320), the compensation can be divided into two types, namely: financial and non-financial compensation. Financial compensation consisted of financial compensation and indirect compensation. Direct financial compensation consists of salaries, wages, bonuses and commissions, while indirect financial compensation, also 
known as allowances covering all the financial rewards are not covered in direct compensation. Non-financial compensation consists of satisfaction received from either of the work itself, such as responsibility, opportunity for recognition, the chance of their campaign, or from the environment psychological and or physical where the person is located, such as co-workers were pleasant, sound policies, the cafeteria, sharing work and their leisure time. Compensation is an important factor affecting how and why people work in an organization and not other organizations. Thus, the compensation granted to employees as a reward for the work and responsibilities given to the company (Mathis \& Jackson, 2009: 419). Thus the compensation is not only related to monetary rewards (extrinsic) alone, but also on the purpose and organization intrinsic rewards such as recognition and promotional opportunities.

\section{Organizational Culture}

Every organization has a culture are different from each other, so as to distinguish one organization to another organization. Culture will encourage people to behave in a certain organization. Organizational culture can affect all the activities of employees in the organization, how they perform, how to look at the work, working with colleagues, and look to the future (Gibsons, 2003: 128). Organizational culture is a system of values of the organization and will affect the way work is done and how employees behave. It can be concluded that the definition of organizational culture in this study is the value system of the organization held by members of the organization, which then affects the way to work and behavior of the members of the organization (Cushway \& Lodge, 2000). To know the power of something culture of the organization, can be identified by three characteristic. First, the viscosity of the culture, as measured by the number of shared assumptions. Viscous culture has a lot of assumptions, whereas the aqueous culture has a few assumptions. Second, the level of togetherness, which layer upon layer of confidence are shared. Third: regulatory clarity (Bacal, 2004).

\section{Emotional Intelligence}

The term of Emotional intelligence contains two syllables, the emotions and intellect. Literally intelligence can be defined as a person's level of brilliance and emotion as a multidimensional phenomenon as a demonstration of the level of subjective feelings. Emotions also mean biological and psychological responses that move our bodies in a particular reaction. Emotional intelligence is the ability as the ability to motivate you and endure the frustration, impulse control and not exaggerating pleasure, set the mood and keep the load stress does not overwhelm the capacity to think, empathize and pray. So, the emotional intelligence of oneself is including self-control, passion, persistence, and the ability to motivate you (Daniel Goleman, 2001: 45). Emotional intelligence as a subset of social intelligence that involves the ability to monitor feelings and emotions of both themselves and others, to sort through them all and use this information to develop thoughts and actions (Salovey \& Meyer, cited in Sumiyarsih, 2012)

\section{Job Satisfaction}

Basically the job satisfaction is individualized, because each person has a different level of satisfaction varies according to the value system espoused. Job satisfaction is "the way the employee feels about his / her job (Wexley \& Yulk; cited in As'ad, 2001: 104). Another view explaining satisfaction or dissatisfaction with one's job is a condition that is subjective is the result of conclusions based on a comparison of what is real is received by an employee from his job as compared to what was expected, desired, and they'd expected as the proper thing or entitled him (Gomes, 2002: 178).

Job satisfaction is basically something individual. Each individual has a level of satisfaction varies according to the value system that applies to him. The higher the perceived assessment of the activities in accordance with the desire of individuals so can make the higher the satisfaction with the activity. Thus, satisfaction is an evaluation that describes someone on feeling his attitude happy or not happy, satisfied or not satisfied at work (Rivai, 2009: 475). Several previous studies find a positive and significant impact on the performance of employee job satisfaction. Satisfaction of employees or workers will affect their performance. An individual who feels frustrated and not happy (satisfied) in the work environment, it will not provide maximum performance for the organization (Adair, 2008). Employees who get job satisfaction will do the job better. In a lot of practice, it is often a positive relationship between job satisfaction and higher with higher employee performance, but it is not always strong enough (significant).Many employees with a high satisfaction but not making employees productive, but still just a mediocre employee. Job satisfaction itself, is not a strong motivator to improve employee productivity

\section{Employee Performance}

Job performance is the successful achievement roles that gain from their actions (Lowler \& Porter, 1968; cited in Gani, 2006). In general, the performance (performance) can be defined as a person's success in executing a job. Both restrictions that provide understandings of job performance are the results achieved by the 
size of the person applying for a job are concerned. Performance is the real behavior shown by everyone as the resulting performance by employees in accordance with its role within the company. Therefore, the performance of employees is very important in the company's efforts to achieve its goals (Rivai, 2009: 309).

According to Mathis \& Jackson (2009: 113), there are three factors that affect the performance of employees, namely: (1) the ability of individual employees includes aptitude, interest and personality factors. The skill level is an employee-owned raw material in the form of knowledge, understanding, ability, interpersonal skills and technical prowess. (2) Businesses that devoted employees for the company is the work ethic, attendance and motivation. The level of effort is a picture of employee motivation shown to finish the job properly. From that if employees have a high capability but do not have a high effort also then the performance will not be good. (3) Organizational support demanding enterprise facilities include training and development of employees, equipment, technology and management.

Individual performance is the employee's performance in terms of both quality and quantity based on the standard of work that has been determined. The individual performance will be achieved if supported by individual attributes, work effort and support organization. In other words, the individual performance is the result of individual attributes that determine the capacity to grind. Individual attributes include individual factors and psychological factors. Individual performance is also the result of work effort that makes up the desire to achieve something. Individual performance is the result of the support organization that provides an opportunity to do something.

\section{Methods}

This study is a survey that attempts to analyze populations large and small with selecting and analyzing a selected sample of the population to be distributed and on the interrelation of the variables sociological and psychological. This method was chosen because it can include a variety of phenomena as such and can allow a broader study conducted because of the relationship of various variables studied. This study also measured the causal relationship between exogenous with endogenous variables. This study will be conducted on 335 employees who work on implementing unit implementing the parent and the entire unit PT. PLN (Persero) south and West Sulawesi which includes Branch, Sector, Area Distribution and Load Control System South Sulawesi (AP2B), and the Settings area Distribution (APD) Makassar. Questionnaire data that has been collected is processed by using Structural Equation Modeling (SEM) with Analysis of Moment Structures (AMOS) Version 18.0.

\section{Analysis of a moment structures (First Stage)}

\section{Results}

Is a good model of a hypothetical model development is theoretically supported by empirical data. Based on the Goodness of Fit Indices (GFI), the criteria of the model as well as critical values that have compatibility of data can be seen in the following table:

Table 1. Goodness of fit indices overall model (First Stage)

\begin{tabular}{|l|c|c|c|}
\hline \multicolumn{1}{|c|}{ Goodness of fit index } & Cut-off Value & Results & Description \\
\hline Chi_Square & Expected of slight & 26741.653 & Marginal \\
\hline Probability & $\geq 0,05$ & 0,000 & Marginal \\
\hline CMIN / DF & $\leq 2,00$ & 17547 & Marginal \\
\hline GFI & $\geq 0,90$ & 0,955 & Marginal \\
\hline TLI & $\geq 0.94$ & 0,909 & Marginal \\
\hline CFI & $\geq 0,94$ & 0,852 & Good \\
\hline RMSEA & $\leq 0,08$ & 0,078 & \\
\hline
\end{tabular}

The table shows that the Goodness of fit indices overall early stage model show fit model is still marginal (not good), From the table above, it appears that there are criteria have not been met, except GFI and RMSEA were quite good, so this model is not fit for use. The necessary modifications to improve the model to be used for verification of research hypotheses.

\section{Analysis of a moment structures (Final Stage)}

Table 2. Goodness of fit indices overall model (Final Stage)

\begin{tabular}{|l|c|c|c|}
\hline \multicolumn{1}{|c|}{ Goodness of fit index } & Cut-off Value & Results & Description \\
\hline Chi_Square & Expected of slight & 265.457 & Good \\
\hline Probability & $\geq 0,05$ & 0,197 & Good \\
\hline CMIN / DF & $\leq 2,00$ & 0,177 & Neither \\
\hline GFI & $\geq 0,90$ & 0,968 & good \\
\hline TLI & $\geq 0.94$ & 0,960 & good \\
\hline CFI & $\geq 0,94$ & 0,976 & good \\
\hline RMSEA & $\leq 0,08$ & 0,042 & good \\
\hline
\end{tabular}


The table is explained that the relationship between variables in the model at a late stage showed a good agreement, so that it can be stated that the causality between each variables tested are acceptable and can be used for analysis.

\section{Leadership on Job Satisfaction}

Leadership is the ability to influence people to achieve organizational goals. The leaders have the authority to direct the various activities led directly and can also affect how the subordinates carry out his orders (Richard L. Daft, 2006: 313). The results show that the leadership has a positive and significant impact on job satisfaction. This is demonstrated by the critical ratio values $>1.96$ and a probability value $<\alpha=0.05$, which is required, in which the critical ratio value obtained for 4.092 to $0.025 \leq 0.05$ significance level. Coefficient of leadership on job satisfaction mounted to 0.226 , leadership means that the better it will improve job satisfaction. In connection with this study, we can conclude that on the whole the indicators that make up the leadership variables proved to have a significant impact. the empirical evidence linking leadership and job satisfaction showed results consistent with this study, as is done by Hamzah (2011), the result proves that leadership is positive and significant effect on job satisfaction. Robbins (2007: 432) suggests that the leadership that uses the behavior of respect, foster cooperation, encourage morale, and help subordinates to achieve goals, which in turn will increase employee job satisfaction.

\section{Compensation on Job Satisfaction}

Compensation is everything received by employees as remuneration for the work that has been done within the organization either directly in the form of money (Financial) and indirectly in the form not of money (non-financial). Direct financial compensation consists of salaries, wages, bonuses and commissions, while indirect financial compensation, also known as allowances covering all the financial rewards are not covered in direct compensation (Mondy \& Noe, 2003: 320). Employee's compensation can be important in the application of human resource management because it can affect employee satisfaction. The test results show that the compensation has a positive and significant impact on job satisfaction. This is indicated by the value of the critical ratio $>1.96$ and a probability value $<\alpha=0.05$, which is required, in which the critical ratio value obtained for 6,099 to $0,000 \leq 0.05$ significance level. Value of the coefficient of compensation on job satisfaction is equal to 0.356 , meaning that the better the compensation will increase job satisfaction. It can be concluded that on the whole the indicators that make up the compensation variables proved to have a significant impact. Empirical evidence linking compensation with job satisfaction showed results consistent with this study, as stated by Supatmi et al. (2013); Siti Arofah (2015) the results of which concluded that the compensation positive and significant effect on job satisfaction. Furthermore Bernardin \& Russell (1993: 373) argues that the compensation is significance to the withdrawal of employees, motivation, performance and productivity. Provision of compensation to employees is very important for the company's goals can be achieved. An optimal compensation awarded will be able to create maximum job satisfaction to employees. The award of compensation is to provide job satisfaction to employees. This means that if companies provide compensation in accordance with the expectations of employees it will create job satisfaction (Mondy \& Noe, 2003).

The main purpose of the compensation is to earn a living, so that the employee and his family can live on its efforts. In other words, employees want to work caused find that the work that the employee will be compensated as a source of income to support himself and his family. Therefore, the objectives of the organization to provide compensation to the employees is that they feel secure their livelihoods. The principle of fair and reasonable must be addressed as well as possible so that the remuneration given to stimulate the spirit as well as employee satisfaction, as well as encouraging employees to work well. Therefore, in granting such compensation, the level or amount of compensation should really be considered as the level of compensation will determine the style of life, dignity and the value of the organization itself.

\section{Organizational Culture on Job Satisfaction}

Organizational culture is a system of organizational values held by members of the organization, which then affects the way to work and behavior of the members of the organization. According Gibsons (2003: 128), organizational culture can affect all employees in the organization's activities, including how they are performing, how to look at the work, working with colleagues, and look to the future. To increase job satisfaction and employee performance are indispensable organizational culture that guide thinking and action for employees in achieving their goals in the future. The test results provide evidence that organizational culture has a positive and significant impact on job satisfaction. This is indicated by the value of the critical ratio $>1.96$ and a probability value $<\alpha=0.05$, which is required, in which the critical ratio value obtained for 4,585 to 0,011 $\leq 0.05$ significance level. The value of the coefficient of influence of leadership to job satisfaction is equal to 0.207 , meaning that the better the organizational culture will increase job satisfaction. Of overall indicators that make up the organizational culture variables proved to have a significant impact. Empirical evidence linking 
organizational culture and job satisfaction showed results consistent with this study, Melina \& Intan (2012) the results concluded that organizational culture positive and significant effect on job satisfaction. Robbins (2007: 36) points out some important factors that bring more job satisfaction, namely: a job that gives an opportunity to use skills, and feedback about how well they work, the next factor is how the working conditions of employees, both in terms of personal comfort and ease of doing the job, these things are closely related to the rules and standards set by the company, whereas the established rules and standards of organizational culture within the company itself.

\section{Emotional Intelligence on Job Satisfaction}

Emotional intelligence is the ability as the ability to motivate yourself and endure the frustration, impulse control and not exaggerating pleasure, set the mood and keep the attitude that the stress load does not cripple the ability to think, empathize and pray, According to Wong et al, (2010) who have high emotional intelligence is Able to understand himself and the emotions of others. Every individual in an organization has a good emotional, growing niche to have the willingness and improving quality in work. Therefore, to increase of job satisfaction and employee performance in an organization really needed a leader who is Able to move throughout the organization to work well. The results show that emotional intelligence has a positive and significant impact on job satisfaction. This is indicated resources by the value of the critical ratio $>1.96$ and a probability value $<\alpha=0: 05$, which are required, in the the critical ratio value Obtained for 4296 with 0.022 significance level of $\leq 0: 05$. The value of the coefficient of the influence of emotional intelligence on job satisfaction is equal to 0209 , meaning that the better the emotional intelligence will increase of job satisfaction.

The ability to handle emotions with others, and indicators capable of take the initiative to act effectively, so Reviews These three indicators that need to be maintained. While the indicator Gives the average value loading factor of the lowest is shown by the indicator are Able to align Themselves with others, being Able to manage emotions, uplifting, have a benchmark to control emotions, and indicators maintain a relationship with another person, where These indicators need to be Increased to the maximum by increasing the ability of aligning Themselves with others, the ability to manage emotions, stimulating employees, has a benchmark in controls emotions, and strive to continue to maintain good relations with others. Thus, increasing the emotional intelligence also increase the job satisfaction of employees in the future.

In connection with this study, we can conclude that on the whole the indicators that make up emotional intelligence proved to have a significant impact. Employees who have better emotional intelligence will have a higher job satisfaction. The ability of employees in processing and use emotions intelligently in work is an important part and should be maintained continuously and maintained. Empirical evidence linking emotional intelligence and job satisfaction showed results consistent with this study, Supriyanto \& Troena (2012) in research proves emotional intelligence significantly influence employee satisfaction. In his research showed that emotions play an important role in job satisfaction; managers who have high emotional intelligence are more satisfied with their jobs than managers who have low emotional intelligence. Gunduz et.al. (2012) show that emotional intelligence is vital to the internal job satisfaction. Employees with high emotional intelligence have higher job satisfaction and the opportunity to leave the company less than the employees who have low job satisfaction (Nair et al., 2010).

\section{Leadership on Employee Performance}

Test results showed that the leadership has a positive and significant influence on employee performance. This is indicated by the value of the critical ratio $>1.96$ and a probability value $<\alpha=0.05$, which is required, in which the critical ratio value obtained for 3.012 with 0.030 significance level of $\leq 0.05$. The value of the coefficient of influence of leadership on employee performance is equal to 0,201 ; leadership means that the better it will improve the performance of employees. Employee performance can be improved through the award of the management, the monitoring of the progress of the work of subordinates to be more intensified, needs to be improved to better accommodate subordinates in the execution of the task, providing clear guidance to subordinates in completing the work, inspire subordinates in the execution of duties, need to be improved by encouraging subordinates to more innovation in the implementation of the tasks still need to be improved by showing the work of a professional so that it becomes a model for subordinates in the execution of the task, it still needs to be improved by establishing an atmosphere of harmonization of co-workers well, always encourage increased intellect subordinates, including continuing education to a higher level or to include subordinates in various training activities related to the performance of its duties, discuss the performance of subordinates including subordinates who are unable to complete its work premises $\mathrm{n}$ good as expected.

Empirical evidence linking employee performance leadership with demonstrated results consistent with this study, as stated Bass (1990); Sudarmasto (2000: 86-88); Muhammad Su'un (2007); Baso Amang (2009); Mukhtar Hamzah (2011), the result concluded that leadership positive and significant effect on employee performance. Empirical findings resulting from this research is that there is a direct and significant influence between leadership with employee performance. 


\section{Compensation on Employee Performance}

Test results show that the compensation has a positive and significant influence on employee performance. This is indicated by the value of the critical ratio $>1.96$ and a probability value $<\alpha=0.05$, which is required, in which the critical ratio value obtained for 5,289 to $0,001 \leq 0.05$ significance level. Value of the coefficient of influence Compensation on employees performance is 0.304 , meaning that the compensation the better it will improve performance.

Employee performance can be enhanced through the fulfillment of the needs of employees who must be supported by an adequate salary, bonuses corresponding working time overtime, allowances adequate in accordance with the role or position of the employee, provide social security as expected, give confidence to each employee's account duties, employees promoted at a higher position, giving recognition to the achievements of employees, delegation of authority to effect policies to employees, and provide the opportunity for employees to participate in decision-making.

The application of the compensation system is the basis for employees to know the portion of compensation that will be received if the employee in performing the task with good skills and knowledge. The amount of remuneration has been determined and known in advance, so that employees exactly know the amount of remuneration or compensation they will receive. The compensation is indeed the result of the sale of the employees of the organization or company. However, this implies that the employee has given all his abilities to the organization. Organization duly appreciate the efforts of the employees by giving appropriate compensation to performance. Empirical evidence linking compensation with employee performance showed results consistent with this study, as shown in studies Eko Supatmi Mamik, Umar Nimran \& Hamidah Nayati Utami (2013); Siti Arofah (2015); the results of which concluded that the compensation positive and significant effect on employee performance. Furthermore Bernardin \& Russell (1993: 373) argues that the compensation is significance to the withdrawal of employees, motivation, performance and productivity. Empirical findings resulting from this research is that there is a direct and significant influence between compensation and employee performance.

\section{Organizational Culture on Employee Performance}

Test results provide evidence that organizational culture has a positive and significant influence on employee performance. This is indicated by the value of the critical ratio $>1.96$ and a probability value $<\alpha=$ 0.05 , which is required, in which the critical ratio value obtained for 2,501 to $0,033 \leq 0.05$ significance level. The value of the coefficient of influence of organizational culture on employee's performance is equal to 0,243 , which means that the better the organizational culture will improve employee performance. Employee performance can be improved through positive thinking either about themselves or others, be more objective in assessing, analyzing and making decisions, are more consistent in every step, have to comply with existing regulations, helping fellow colleagues in the office, maintaining the company's facilities, willing to share his knowledge, and empower others to come forward.

Organizational culture in general talks about values, trust, commitment, discipline, sense of Carries responsibility for the tasks assigned by the leaders, and the behavior of individuals within the organization. The value of the identity of the organization that became the difference with other organizations. An organizational culture that is social environment for the creation of a good and healthy organization evidenced by the achievement of organizational performance productivity actors therein. The values guiding the individual in the face of external and adjustment problems of integration in the enterprise, so that he can apply the values to act and behave. Empirical evidence linking organizational culture with employee performance showed results consistent with this study, as stated Chaterina Melina Taurisa \& Intan Ratnawati (2012); the results concluded organizational culture positive and significant effect on employee performance. Empirical findings resulting from this research is that there is a direct and significant influence between organizational cultures with employee performance.

\section{Emotional Intelligence on Employee Performance}

The complete test results showed emotional intelligence has a positive and significant influence on employee performance. This is indicated by the value of the critical ratio $>1.96$ and a probability value $<\alpha=$ 0.05 , which is required, in which the critical ratio value obtained for 4.397 with a significance level of $0.010 \leq$ 0.05 . The value of the coefficient of the influence of emotional intelligence) on the performance of employees is equal to 0.205 , meaning that the better the emotional intelligence will improve employee performance. Employee performance can be improved by trying to understand the emotions themselves, have a benchmark to control emotions, always trying to be able to manage emotions, always expressing emotions appropriately, can take the initiative to act effectively, always uplifting employees, always understand the perspectives of others, always able to align themselves with others, always handle emotions with others, maintaining good relations with others. Thus, increasing the emotional intelligence also increase the performance of employees in the future. 
Emotional intelligence is the ability to control emotions by not easily shaken or broken in the face of various challenges and problems. Prophet taught, called the strong man is not the one who heavies, can defeat the enemy force with the power. An intelligent person is one who is able to control themselves and do for tomorrow, in preparation for the long term. Emotional intelligence is determines whether employees are able to confront reality with a positive impression that produces high performance or vice versa. According to Goleman (2000), the more complex the job, the more important emotional intelligence. Moreover, because of the deficiency in the ability of a person's emotional, may be impaired in the use of technical expertise or dilution brain. This opinion confirms that the performance of the brain alone is not sufficient to obtain results with high performance, but requires the involvement of emotional intelligence. The core of emotional intelligence is how one's relationship and communication with others in order to obtain and obtained the harmonious relationship mutually beneficial reciprocity. Someone who can optimally express his power to achieve optimal results and their relationships is when one is able entwined in packaging wonderful jobs. Gina (2007) stated that during this emotional relationship can be established with the "beautiful" will generate a beautiful relationship anyway. Vice versa, if the feeling was not intertwined relationship with the "beautiful", it will result in lower performance. Thus, emotional intelligence is able to support increased employee performance.

Empirical evidence linking emotional intelligence and employee performance showed results consistent with studies Achmad Sani Supriyanto (2012) that emotional intelligence has significant influence on employee performance. Furthermore Virk (2011) that emotions play an important role in job satisfaction, managers who have high emotional intelligence are more satisfied with their jobs than managers who have low emotional intelligence. Empirical findings resulting from this research is that there is a direct and significant influence between emotional intelligence and employee performance.

\section{Leadership on Employee Performance through Job Satisfaction}

Test results showed that the leadership has a positive and significant impact on the performance of employees through job satisfaction as an intervening variable. This is indicated by the value of the critical ratio of $1.96 \geq 3.012$ and 0.030 probability value $\leq 0.05$ required. This means the leadership and employee performance variables have a causal relationship positive and significant. The positive influence of leadership on employee performance through job satisfaction as an intervening variable is determined by the ten indicators that make it up are: received an award from the President, the progress of the work of subordinates, to accommodate subordinates, providing clear direction, inspire subordinates, encourage innovation, modeling subordinates, atmosphere harmonization co-workers, an increase in intellect, and discuss the performance of subordinates.

To determine the effect (direct effect) between leadership and employee performance as indicated by the positive direction of 0,201 and indirect effects (indirect effects) through job satisfaction and a positive value 0.055 , so that the total effect is obtained figure of 0.256 . Furthermore Sobel Test Statistic results obtained value of $\mathrm{z}=2.501>1.96$ or probability value ( $\mathrm{p}$-value) was obtained for $0.012<0.05$ are required. This means that the leadership does not directly affect the performance of the employees but first need the job satisfaction of employees. Thus, the leadership will increase job satisfaction, so that when employee satisfaction is adequate or high, then the performance of employees will increase or it can be said job satisfaction as an intervening variable is able to strengthen these two variables significantly.

Empirical evidence linking employee performance leadership with demonstrated results consistent with this study, as proposed Bass (1990); Sudarmasto (2000: 86); Muhammad Su'un (2007); Baso Amang (2009), Mukhtar Hamzah (2011), Endang Sukarjati, Mary Magdalene, Moh Minarsih \& Mukeri Warso (2016) conclude that the results are positive and significant effect of leadership on employee performance. According to Waldman et al., (2001), that the influence of leadership on organizational performance is very possible. Furthermore, according to Nankervis; Cited in Brocklesby (1995: 70), efforts to effectively acquire competencies include: knowledge, skills, expertise and professional attitude that directly contribute to the effectiveness of individual performance. Robbins (2007: 432), also argued that use behavioral appreciate leadership, build teamwork, morale and help encourage subordinates to achieve the goal, it will improve the performance of employees.

\section{Compensation on Employee Performance through Job Satisfaction}

The test results show that the compensation has a positive and significant impact on the performance of employees through job satisfaction as an intervening variable. This is indicated by the value of the critical ratio of $1.96 \geq 5.289$ and 0.001 probability value $\leq 0.05$ required. This means that the variable compensation and employee performance have a causal relationship positive and significant. The positive effect of compensation to employee performance through job satisfaction as an intervening variable is determined by the ten indicators that make it up are: salary support fulfillment, bonus according overtime, allowances appropriate role / position, social security as expected, confidence accountable for their work, promoted on higher office, in recognition of the achievements of employees, delegation of authority policy and participate in decision making. 
To determine the effect (direct effect) between compensation and employee performance as indicated by the positive direction of 0.304 and indirect effects (indirect effects) through job satisfaction and a positive value 0.155 , so that the total effect is obtained figure of 0,459 . Furthermore Sobel Test Statistic results obtained value of $z=3.578>1.96$ with a probability value ( $p$-value) was $0.000<0.05$ are required. This means that the compensation does not directly affect the performance of employees but first needs to support job satisfaction of employees. Thus, the compensation will increase job satisfaction that when employee satisfaction is adequate or high, then the performance of employees will increase or it can be said job satisfaction as variable an intervening is able to strengthen these two variables significantly.

Empirical evidence linking compensation with employee performance showed results consistent with these studies, such as Mamik Eko Supatmi, Umar Nimran \& Hamidah Nayati Utami (2013) which concluded that the compensation results are positive and significant effect on employee performance. Farmer (2008) conducted a study on the relationship between the compensation received by the CEO of the company in the United States and the United Kingdom with the company's performance. Results from the study indicate that compensation is positively and significantly affect the company's performance. Research conducted Eko Muryanto (2011) also explains that compensation is a significant and positive effect on employee performance.

Dessler (2003) suggested the employee compensation is any form of payment or benefits granted to employees and arising from the employment of the employee. In this case, since the beginning it has become a motivation in doing any activities within the company. Therefore, compensation becomes a very important part in the process evaluation of employees themselves to decide whether the employee is satisfied or not in a company. Compensation that provides job satisfaction is employee compensation needs to be seen to what extent the company can reward employees. The impact of job satisfaction will affect the performance of employees. The higher the satisfaction received by employees will be compensated by the company will increasingly make better employee performance at work and conversely the lower the satisfaction with compensation the employee's performance will decrease.

\section{Organizational Culture on Job Satisfaction through Employee Performance}

Test results showed that organizational culture has a positive and significant impact on the performance of employees through job satisfaction as an intervening variable. This is indicated by the value of the critical ratio of $1.96 \geq 2.501$ and 0.033 probability value $\leq 0.05$ required. This means that variable of organizational culture and employee performances have a causal relationship positive and significant. The positive influence of organizational culture on employee performance through job satisfaction as an intervening variable is determined by eight indicators that make it up are: thinking positively about yourself and others, be objective in assessing, analyzing and making decisions, consistent in every step, comply with regulations no, help colleagues, maintaining company facilities, are willing to share their knowledge, and empower others to come forward.

To determine the effect (direct effect) between the culture of the organization with the employee's performance as indicated by the positive direction of 0,243 and indirect effects (indirect effects) through job satisfaction and a positive value 0,046 , so the total effect is obtained figure of 0.289 . Furthermore Sobel Test Statistic results obtained value of $z=4.166>1.96$ with a probability value ( $p$-value) was $0.000<0.05$ are required. This means that the organizational culture does not directly affect the performance of employees but first there needs to be job satisfaction of employees. Thus, the culture of the organization will increase the job satisfaction that when employee satisfaction is adequate or high, then the performance of employees will increase or it can be said job satisfaction as an intervening variable able to strengthen these two variables significantly.

According Trihandini (2005) that the working world has many problems and challenges that must be faced by employees, such as competition, the demands of the task, and uncomfortable work atmosphere and relationship problems with others. These problems require not only intellectual ability, but also require the ability of emotion or emotional intelligence. If one can solve the problems in the world of work associated with his emotions then he will produce better work. Goldman (2000) states that to achieve success in the world of work not only cognitive intelligence is needed but also emotional intelligence. In particular the leaders of the company requires a high EQ for the organizational environment, interacting with people both at home and in the work environment plays an important role in shaping the moral and discipline of the workers. Empirical evidence linking organizational culture with employee performance showed results consistent with this study, as proposed Catherina Melina Ratnawati Taurisa \& Diamonds (2012); Filliks Duwit (2015); Siti Khanifah (2015); which concluded that organizational culture positive and significant effect on employee performance.

\section{Emotional Intelligence on Employee Performance through Job Satisfaction}

Test results show that emotional intelligence has a positive and significant impact on the performance of employees through job satisfaction as an intervening variable. This is indicated by the value of the critical 
ratio of $1.96 \geq 4.397$ and 0.010 probability value $\leq 0.05$ required. This means variable emotional intelligence and employee performance have a causal relationship positive and significant. The positive effects of emotional intelligence on the performance of employees through job satisfaction as an intervening variable is determined by the ten indicators that make it up are: understand the emotions themselves, have a benchmark to control emotions, being able to manage emotions, capable of expressing emotions appropriately, able to take the initiative to act effectively, uplifting, able to understand the perspectives of others, are able to align themselves with others, the ability to handle emotions with other people, maintains relationships with others.

The direct effect between emotional intelligence and employee performance as indicated by the positive direction of 0.205 and indirect effects through job satisfaction and a positive value 0.091 , so that the total effect is obtained figure of 0,296. Furthermore Sobel Test Statistic results obtained value of $\mathrm{z}=2.838>$ 1.96 with a probability value (p-value) was obtained for $0.017<0.05$ are required. This means that emotional intelligence does not directly affect the performance of the employees but first there needs to be job satisfaction of employees. Thus, emotional intelligence will increase job satisfaction that when employee satisfaction is adequate or high, then the performance of employees will increase or it can be said job satisfaction as an intervening variable is able to strengthen these two variables significantly. Thus, it can be said that the eleventh hypothesis (H12) which states that emotional intelligence is a positive and significant effect on the performance of employees through job satisfaction is proven and supported by facts and empirical data.

Martin (2000); Cited in Trihandini (2005) explains that the employee's performance is not only seen from a perfect work ability but also the ability to control and manage themselves as well as the ability to control and manage themselves as well as the ability to build relationships with others. These capabilities by Goleman (2006: 512) referred to as emotional intelligence or emotional intelligence is the ability of a person regulate emotional life with intelligence (to manage our emotional life with intelligence), maintain alignment of emotion and expression (the appropriateness of emotion and its expression) through skills self-awareness, self-control, self-motivation, empathy and social skills. Empirical evidence linking emotional intelligence and employee performance showed results consistent with this study, as proposed Chaterina Melina Taurisa \& Intan Ratnawati (2012); Filliks Duwit (2015); Siti Khanifah (2015); which concluded that emotional intelligence is a significant and positive effect on employee performance. These results also support Robbins (2012) which states that emotional intelligence will be able to improve the performance of employees.

\section{Job Satisfaction on Employee Performance}

Test results showed that job satisfaction has a positive and significant influence on employee performance. This is indicated by the value of the critical ratio of $1.96 \geq 7.417$ and 0.000 probability value $\leq$ 0.05 required. This means job satisfaction and employee performance have a causal relationship positive and significant. The positive effect of job satisfaction variables on the performance of employees is determined by the indicators that make it up are: form an interesting job, gives a sense of achievement, benefits, awards, modern equipment, adequate equipment, support co-workers, mutual aid, support from partners, accept criticism and suggestions from partners, calmly deal with the problem, and avoid the pressures that lead to a feeling of frustration.

The test results Confirmatory Factor Analysis job satisfaction variables indicate that avoid the pressures feeling that leads to frustration, form an interesting job, peer support, adequate equipment, awards, and gives a sense of achievement influence in shaping employee satisfaction with the value of the loading factor began to 0.838 up to 0.953 . Therefore, these indicators need to be maintained in order to form a support job satisfaction employee performance improvement in the future. The indicator that provides value loading factor is the smallest of benefits, has the support of partners such modern equipment, accept criticism and suggestions from partners, and calmly deal with the problem. The interval values of loading factor between 0.559 to 0.789. Therefore, these indicators need in order to form a variable level of job satisfaction which in turn support improved employee performance in the future.

Job satisfactions have a significant effect on employee performance. A positive coefficient indicates job satisfaction have a positive influence on employee performance. This means that the higher the job satisfaction of employees, the employee's performance will be higher as well. Conversely, the lower the job satisfaction of employees, the employee's performance will also be lower. Empirical evidence linking job satisfaction and employee performance showed results consistent with this study, as proposed sajib \& Thomas (2008) that the employee or worker satisfaction will affect their performance. Adair (2008) that an individual who feels frustrated and not happy (satisfied) in the work environment, it will not provide maximum performance for the organization. In a previous study also suggested that job satisfaction has a significant impact on the performance of employees, such as those found Umar Akmal (2010); Mukhtar Hamzah (2011); Melina Chaterina Taurisa \& Intan Ratnawati (2012); Achmad Sani Supriyanto (2012); Mamik Eko Supatmi, Umar Nimran \& Hamidah Nayati Utami (2013); Endang Sukarjati, Maria Magdalena Moh Minarsih \& Mukeri Warso (2016). The relationship of job satisfaction and employee performance is the direction (positive). The factors of emergence are employee satisfaction level in this study, among others: a challenging job, reasonable compensation, working conditions support, peer support, and the support of partners (Robbins, 2007: 112). 


\section{Conclusion}

Leadership has a direct influence positive and significant impact on job satisfaction. This means the effective leadership of then also increases the job satisfaction of employees. Compensation has direct influence positive and significant impact on employee satisfaction. This means that the suitability of the compensation it is also increase the job satisfaction of employees. Cultural organizations have direct influence positive and significant impact on job satisfaction. This means that the more effective the organization's culture also increase the job satisfaction of employees. Emotional intelligence has a direct positive influence and significant impact on job satisfaction. This means increasing the emotional intelligence also increase the job satisfaction of employees.

Leadership has a direct positive influence and significant impact on employee performance. This means the effective leadership of the employee's performance is increasing as well. Compensation has a direct positive influence and significant impact on employee performance. This means more and adequate compensation, the employee's performance will be increasing as well. Cultural organizations have direct influence positive and significant impact on employee performance. This means the better the culture of the organization then also increases the performance of employees.

Emotional intelligence has a direct positive influence and significant impact on employee performance. This means increasing emotional intelligence, the higher the performance of employees. Coefficient of direct effect between leadership and employee performance and the indirect effect through job satisfaction and a positive value, and the total effect shows the impact of job satisfaction that can strengthen leadership relationship with employee performance. Coefficient of direct effect between compensation and performance of employees and indirect effects through job satisfaction and a positive value, and the total effect shows the impact of job satisfaction that can strengthen the relationship between compensation and employee performance. Coefficient of direct effect between the culture of the organization with the performance of employees and indirect effects through job satisfaction and a positive value, and the total effect shows the impact of job satisfaction that can strengthen the relationship between organizational cultures with employee performance.

Coefficient of direct effect between emotional intelligence and employee performance and the indirect effect through job satisfaction and a positive value, and the total effect shows the impact of job satisfaction that can strengthen the relationship between emotional intelligence and employee performance. Job satisfaction has a direct positive influence and significant impact on employee performance. These means increased job satisfaction then also increase the performance of employees. Required maximum attention of the management company, that in order to achieve job satisfaction and employee performance are high it will need effective leadership, adequate compensation, good organizational culture, and high emotional intelligence, because these aspects are an important element in ensuring the life organization at all levels. Emotional intelligence is the variable that the smaller the impact on job satisfaction and employee performance so it should get priority for review at the next study because it is one very important element in improving job satisfaction and employee performance in the future.

Leadership still need to be effected by creating a harmonious atmosphere of co-workers, to accommodate the implementation of the tasks of subordinates, modeling subordinates, discuss the performance of subordinates effectively, giving awards to subordinates who excel, inspire subordinates effected, trying to encourage subordinates to innovate and continue to monitor the progress of work subordinates in order to increase job satisfaction, which in turn will improve the performance of employees in order to improve job satisfaction which in turn will improve the performance of employees.

Compensation needs to be enhanced by giving credence accountable for their work to each employee, streamline policy delegation of authority for employees, provide social security as expected of employees, provide the opportunity for employees to participate in decision making, so as to increase job satisfaction, which in turn will improve the performance of employees. Organizational culture needs to be improved to maintain the attitude to be consistent in every step and always be objective in assessing, analyzing and making decisions. Similarly, other indicators also need to be improved include always think positively about yourself and others, always comply with existing regulations, and likes to help co-workers, so as to improve job satisfaction which in turn will improve the performance of employees. Emotional intelligence needs to be improved by increasing the ability to align themselves with others, the ability to manage emotions, stimulating employees, has a benchmark in controlling emotions, and strive to continue to maintain good relations with other people, so it can improve job satisfaction which in turn will increase employee performance.

\section{References}

[1] Adair, John (2008). Leadership and Motivation (the Fifty-Fifty Rule and the Eight Key Principles of Motivating Others). Adapted Fairano Ilyas, Gramedia Pustaka Utama, Jakarta.

[2] Agustian, Ary Gina. (2001). Secrets of Success Building Emotional and Spiritual Intelligence (ESQ). Jakarta: Arga

[3] As'ad, Moh, (2001). Industrial Psychology, Fourth Edition, Prints Nine, Liberty, Yogyakarta 
[4] Bacal, Robert (2004). How to Manage Performance, 24 Important Points to Improve Performance, PT Bhuana Popular Science, Jakarta

[5] Carmeli, A. (2003). The relationship between emotional intelligence and work attitudes, behaviors and outcomes: An examination among senior managers. Journal of Managerial Psychology, 18 (8), 788-813.

[6] Condly, SJ, Clark, RE, \& Stolovitch, HD (2003). The Effects of Incentives on Workplace Performance: A Meta-analytic Review of Research Studies 1. Performance Improvement Quarterly, 16 (3), 46-63.

[7] Cushway and Lodge, 2000, the Human Resource Management. Translation, PT Elex Media Komputindo, Jakarta.

[8] Daniel Goleman, 2006, Emotional Intelligence, Gramedia Pustaka Utama, Jakarta.

[9] Douglas, C., Frink, DD, \& Ferris, GR (2004). Emotional intelligence as a moderator of the relationship between conscientiousness and performance. Journal of Leadership \& Organizational Studies, 10 (3), 2-13.

[10] Duwit, F. (2015). Influence of communication competencies, emotional intelligence, and organizational culture on employee performance. Journal of economic research, management, business and accounting, 3 (4).

[11] Gani, M. Umar, (2006). Influence of Individual Characteristics, Job Characteristics, Organizational Characteristics, Work Motivation, Rewards and Performance, on Employee Satisfaction (Study in Industrial Area Makassar South Sulawesi). Post Graduate Brawijaya University, Malang.

[12] Gibsons James L, John Ivancevich \& James H Donnelly Jr., (2003). Organizational Behavior, Structure and Process, Ali Wahid Djoerban Language, Literacy Binarupa, Jakarta

[13] Gomes, Faustino Cardoso, (2002). Human Resource Management, Andi Offset, Yogyakarta.

[14] Hamzah, Muhtar, (2011). Influence of Organizational Characteristics, Leadership, Work Motivation and Competence on Job Satisfaction and Employee Performance (Study at PT. PLN (Persero) Region Sulselrabar), PPs UMI Dissertation, Unpublished, Makassar

[15] Khanifah, S., \& Palupiningdyah, P. (2015 ). Effect of Emotional Intelligence and Cultural Organization's Performance With Organizational Commitment. Analysis Management Journal, 4 (3).

[16] Khanifah, S., \& Palupiningdyah, P. (2015). Effect of Emotional Intelligence and Cultural Organization's Performance With Organizational Commitment. Analysis Management Journal, 4 (3).

[17] Mathis, Robert L., and John H. Jackson, (2009). Human Resource Management, Ninth Edition, South-Westem College Publishing, Thomson Learning, USA. Jemmy Sadeli \& Bayu Butler Hie (translator), Salemba Four, Jakarta.

[18] Melina Taurisa, C., \& Diamond, R. (2012). Analysis of the influence of organizational culture and job satisfaction on organizational commitment in improving employee performance (Study at PT. Sido Appears Kaligawe Semarang). Journal of Business and Economics, 19 (2).

[19] Monday, R. Wayne \& Noe, Robert M., (2003). Human Resource Management, Allyn \& Bacon

[20] Muhammad Rasbi, (2016),Effect of Effect of Leadership, Motivation, Task Demands on Employee Performance and Reward as an intervening variable in the Ministry of Religion. Dissertation, PPs UMI, Makassar

[21] Rival, Veithzal, (2009). Human Resource Management for the Company, King Grafindo Persada, Jakarta.

[22] Robbins, Stephen P., (2007). Organizational Behavior, translator Benyamin Molan, Indonesian Edition, Complete Edition, Pearson Education, Inc., Upper Saddle River, New Jersey.

[23] Schein, Edgar H., (1992). Organizationl Cultural and Leadership, Jossey-Bass, San Fransisco

[24] Siti Arofah, (2015). Effect of Compensation, Skills and Work Environment on Employee Satisfaction at Permata Bank Branch Kuhl Semarang.

[25] Smith, (1996). Performance Appraisal (State of the Art in Practice). First Edition. Jossey-Bass Publishers. San Fransisco.

[26] Sukarjati, E., Minarsih, MM, \& Warso, MM (2016). Influence of Leadership, Human Resources Development And Job Satisfaction Against Employee Performance Management Office Finance and Asset Semarang City ". Journal of Management, 2 (2).

[27] Sumiyarsih, W., Mujiasih, E., \& Ariati, J. (2012). Relationship Between Emotional Intelligence with Organizational Citizenship Behavior (OCB) on Employee CV. Aneka Ilmu Semarang. Undip Journal of Psychology, 11 (1), 9.

[28] Supatmi, ME, Nimran, U., \& Utami, HN (2013). Effect of training, compensation on employee job satisfaction and employee performance. PROFIT (Journal of Business Administration), 7 (1).

[29] Supriyanto, AS, \& Troena, EA (2012). Effect of Emotional Intelligence and Spiritual Intelligence on Transformational Leadership, Job Satisfaction and Performance Manager (Studies in Bank Shariah Malang) '. Application Management Journal, 10 (4), $693-17$.

[30] Terry, George R., (1977), Principles of Management, Seventh Edition, Richad D.Irwin Inc., Homewood Illinois.

[31] Voydanoff, Patricia, (1980). Work, Family and Community: Exploring Interconnections, New Jersey: Lawrence Elbaum Associates, Inc.

[32] Supatmi, ME, Nimran, U., \& Utami, HN (2013). Effect of training, compensation on employee job satisfaction and employee performance. Profit (Journal of Business Administration), 7 (1).

[33] Melina Taurisa, C., \& Diamond, R. (2012). Analysis of the influence of organizational culture and job satisfaction on organizational commitment in improving employee performance (Study at PT. Sido Appears Kaligawe Semarang). Journal of Business and Economics, 19 (2).

[34] Wong, CS, Wong, PM, \& Peng, KZ (2010). Effect of middle-level emotional intelligence leader and teacher on school teachers' job satisfaction: The case of Hong Kong. Educational Management Administration \& Leadership, 38 (1), 59-70.

\footnotetext{
Ilham Andi Rahman. "Effect of leadership, compensation, organizational culture and emotional intelligence on job satisfaction and employees performance ." IOSR Journal of Business and Management (IOSR-JBM), vol. 19, no. 10, 2017, pp. 13-24.
} 